Terakreditasi SK. No. 040/P/2014

http://jurnal.unmer.ac.id/index.php/jkdp

\title{
UJI EMPIRIS MODEL ASSET PRICING LIMA FAKTOR FAMA-FRENCH DI INDONESIA
}

\author{
Bambang Sutrisno \\ Irwan Adi Ekaputra \\ Departemen Manajemen, Fakultas Ekonomi dan Bisnis, Universitas Indonesia \\ Kampus UI, Depok 16424 - Indonesia
}

\begin{abstract}
The main purpose of this study is to evaluate and compare the performances of the Fama-French three- (FF3) and five-factor (FF5) models in the Indonesia stock market. This study also examines whether book-to-market factor (HML) is redundant in explaining the portfolio excess returns in Indonesia. This study employs asset pricing factor of the $2 \times 3$ sorts and excess returns of 25 Size-B/M, 25 Size-OP, dan 25 Size-Inv portfolios as dependent variables. This study employs Ordinary Least Square (OLS) with monthly time-series data from 2000 to 2015. Based on the average adjusted $R^{2}$ from the two models, FF5 explains portfolio excess return variations better than FF3, although the profitability and investment factors only display weak effect on the excess returns. If we refer to Merton's (1973) zero-intercept criterion, the both modelsare not valid in Indonesia, because most intercepts are significant in each set of 25 portfolios. We also find that book-to-market factor is redundant in describing the variation of returns in Indonesia. The test of intercept difference between Indonesia and The US indicates that there are differences of abnormal return and market efficiency in both countries.
\end{abstract}

Keywords: Fama-French five-factor model, asset pricing, Indonesia stock market

\section{PENDAHULUAN}

Capital Asset Pricing Model (CAPM) yang diperkenalkan oleh Sharpe (1964), Lintner (1965), dan Black (1972) berkontribusi penting terhadap pemahaman hubungan risk dengan return bagi dunia akademisi dan praktisi. Imbal hasil dari suatu aset dalam model CAPM hanya ditentukan oleh risiko sistematik, yaitu beta. Return harapan (expected return) pada aset berisiko berhubungan positif dengan beta.
Seiring dengan perkembangan CAPM, sejumlah penelitian menemukan bahwa tidak hanya beta yang dapat menjelaskan imbal hasil saham, tetapi ada faktor-faktor penjelas lain yang dapat menjelaskan imbal hasil saham dan akhirnya mengembangkan model asset pricing lain. Model tiga faktor ini meliputi faktor market (market excess return), faktor size (SMB), dan faktor book-to-market (HML). SMB (small minus big) merupakan return pada portofolio saham berukuran kecil dikurangi dengan return pada portofolio saham berukuran besar, sedangkan HML

Korespondensi dengan Penulis:

Bambang Sutrisno. HP:+6285336048157

Email: bambangsutrisno89@gmail.com 


\section{Jurnal Keuangan dan Perbankan | KEUANGAN}

Vol. 20, No.3, September 2016: 343-357

(high minus low) merupakan return pada portofolio value stocks dikurangi return pada portofolio growth stocks.

Penelitian-penelitian berikutnya menunjukkan bahwa model tiga faktor dapat menjelaskan cross section dari return saham dengan baik. Penelitian-penelitian ini antara lain dilakukan oleh Fama \& French (1996, 1998), Liew \& Vassalou (2000), Griffin \& Lemmon (2002), dan Lettau \& Ludvigson $(2001,2006)$. Oleh karena itu, model tiga faktor Fama-French telah menjadi model acuan dalam literatur asset pricing.

Fama \& French (2015a) telah memperkenalkan model asset pricing lima faktor. Model lima faktor Fama-French ini merupakan pengembangan dari model tiga faktor (Fama \& French, 1993) dengan menambah dua faktor yang dapat menangkap return premium yaitu faktor profitability dan investment. Model lima faktor ini dimotivasi oleh model diskonto dividen dan temuan-temuan empiris sebelumnya yang menemukan bahwa faktor profitability dan investment mempengaruhi tingkat pengembalian aset.

Fama \& French (2015a) menemukan bahwa model lima faktor lebih baik daripada model tiga faktor dalam menjelaskan excessreturn saham di Amerika Serikat. Mereka juga menemukan bahwa faktor book-to-market(HML) menjadi redundant dalam menjelaskan excessreturn dengan adanya penambahan faktor profitability dan investment. Chiah, et al. (2015) menguji performa model lima faktor Fama-French di pasar saham Australia. Mereka menemukan bahwa model lima faktor Fama-French dapat menjelaskan anomali-anomali asset pricing dengan lebih baik daripada model tiga faktor, yang artinya temuan ini mendukung keunggulan dari model lima faktor. Selain itu, dengan adanya penambahan faktor profitability dan investment, mereka menemukan bahwa faktor bookto-market(HML) tetap memiliki kekuatan penjelas dalam menjelaskan excessreturn di pasar saham Australia. Temuan Chiah, et al. (2015) di Australia ini berbeda dengan temuan Fama \& French (2015a) di Amerika Serikat.

Sebagai salah satu negara berkembang di Asia, Indonesia mempunyai pasar saham yang mulai berkembang di antara pasar saham negaranegara lainnya. Kinerja IHSG menunjukkan tren positif selama beberapa tahun terakhir. Menurut IDX Statistics 2015, total volume perdagangan, nilai perdagangan, frekuensi perdagangan, dan kapitalisasi pasar di Bursa Efek Indonesia pada tahun 2015 masing-masing secara berurutan adalah 1.446.314 juta saham, Rp 1.406.362 miliar, 54.066.252 kali, dan Rp 4.872.702 miliar.

Pasar saham Indonesia merupakan pasar saham yang memiliki volume transaksi perdagangan tipis (thin trading). Implikasi dari thin trading ini adalah ketidaksinkronan perdagangan (nonsynchronous trading) di pasar (Dimson, 1979; Lo \& MacKinlay, 1990;). Nonsynchronous trading disebabkan oleh banyaknya sekuritas yang tercatat tetapi tidak seluruhnya diperdagangkan atau tidak terjadi transaksi.

Penelitian sebelumnya yang melakukan pengujian performamodel asset pricing lima faktor Fama-French lebih fokus pada developed markets, sehingga menarik untuk menguji validitas eksternal model lima faktor tersebut di emerging market seperti Indonesia. Oleh karena itu, penelitian ini akan mengevaluasi performa model tiga faktor dan lima faktor Fama-French secara komprehensif pada pasar saham Indonesia. Selain itu, penelitian ini menguji apakah faktor book-to-market (HML) bersifat redundant dalam menjelaskan excess return portofolio saham di Indonesia. Hasil penelitian menunjukkan bahwa model lima faktor FamaFrench lebih baik daripada model tiga faktor dalam menjelaskan excess return portofolio saham di Indonesia, walaupun faktor profitability dan investment menunjukkan pengaruh yang lemah. Faktor book-to-market terbukti bersifat redundant dalam menjelaskan excess return portofolio saham di Indonesia. 
Fama \& French (2015a) memperkenalkan model lima faktor melalui pengembangan model diskonto dividen dan temuan empiris sebelumnya yang menemukan bahwa banyak variasi dari averagereturn berhubungan dengan profitability dan investment yang tidak dijelaskan oleh model tiga faktor Fama \&French (1993). Melalui pengembangan model diskonto dividen, Fama \& French (2015a) mencoba untuk memperoleh hubungan antara expected return dengan expected earnings, expected investment, dan book-to-market ratio, seperti yang tertulis pada persamaan (1) berikut:

$\frac{M_{t}}{B_{t}}=\frac{\sum_{\tau=1}^{\infty} E\left(Y_{t+\tau}-d B_{t+\tau}\right) /(1+r)^{\tau}}{B_{t}}$

Persamaan (1) memberikan tiga pernyataan tentang expected return saham. Pertama, semuanya tetap kecuali nilai saham saat ini $\left(M_{t}\right)$ dan expected return saham $(r)$. Nilai yang lebih rendah dari $M_{t}$ atau ekuivalen dengan rasio book-to-market equity $\left(B_{t} / M_{t}\right)$ yang lebih tinggi berimplikasi pada $e x-$ pected return saham yang lebih tinggi. Kedua, nilai $M_{t}$ dan semuanya tetap kecuali expected future earnings $\left(Y_{t+\tau}\right)$ dan expected return saham $(r)$. Expected earnings yang lebih tinggi berimplikasi pada expected return saham yang lebih tinggi. Ketiga, untuk nilai $B_{t^{\prime}} M_{t^{\prime}}$ dan expected earnings tetap, maka expected growth pada book equity atau investment $\left(d B_{t+\tau}\right)$ yang lebih tinggi berimplikasi pada expected return saham yang lebih kecil.

Model lima faktor dirumuskan dalam suatu persamaan sebagai berikut:

$R_{i t}-R_{f t}=a_{i}+b_{i}\left(R_{m t}-R_{f t}\right)+s_{i} S M B_{t}+h_{i} H M L_{t}+r_{i} R M W_{t}+$ $c_{i} C M A_{t}+e_{i t}$

Dimana $R_{i t}$ adalah return pada sekuritas atau portofolio $i$ pada periode $t, R_{f t}$ adalah risk-free rate pada periode $t, R_{m t}$ adalah return portofolio pasar pada periode $t, S M B_{t}$ adalah faktor size (Small Minus Big) pada periode $t, H M L_{t}$ adalah faktor bookto-market (High Minus Low) pada periode $t, R M W_{t}$ adalah faktor profitability (Robust Minus Weak prof- itability) pada periode $t, C M A_{t}$ adalah faktor investment (Conservative Minus Aggressive investment) pada periode $t$, dan $e_{\text {it }}$ adalah error termdari sekuritas atau portofolio $i$ pada periode $t$.

Fama \& French (2015a) menguji model tiga faktor dan lima faktor di Amerika Serikat selama periode Juli 1963 - Desember 2013. Mereka menemukan bahwa model lima faktor lebih baik daripada model tiga faktor dalam menjelaskan variasi dari averagereturn saham. Selain itu, mereka juga menemukan bahwa faktor book-to-market (HML) menjadi redundant dalam menjelaskan average return saham dengan adanya penambahan faktor profitability dan investment.

Chiah, et al. (2015) membandingkan performa model tiga faktor dan lima faktor FamaFrench di pasar saham Australia selama periode Januari 1982 - Desember 2013. Mereka menemukan bahwa model lima faktor Fama-French dapat menjelaskan anomali-anomali asset pricing dengan lebih baik daripada model tiga faktor, yang artinya temuan mereka mendukung keunggulan model lima faktor. Dengan adanya penambahan faktor profitability dan investment, mereka menemukan bahwa faktor book-to-market tetap memiliki kekuatan penjelas terhadap variasi return saham. Temuan ini berbeda dengan temuan Fama \&French (2015a).

Fama \& French (2015b) menguji model lima faktor secara internasional yaitu di 23 negara developed markets yang terbagi ke dalam empat wilayah: Amerika Utara, Eropa, Jepang, dan Asia Pasifik selama periode Juli 1990 - September 2014. Mereka menemukan bahwa averagereturn saham untuk Amerika Utara, Eropa, dan Asia Pasifik meningkat seiring dengan book-to-market ratio dan profitability dan secara negatif berhubungan dengan investment. Pola average return saham ini kuat untuk untuk saham-saham kecil tetapi lebih lemah untuk saham-saham besar. Untuk Jepang, hubungan antara rata-rata return dengan rasio book-to-market equity kuat untuk semua kelompok Size, tetapi average return menunjukkan hubungan yang lemah dengan 


\section{Jurnal Keuangan dan Perbankan | KEUANGAN}

Vol. 20, No.3, September 2016: 343-357

profitability atau investment. Faktor book-to-market (HML) tidak redundant atau tetap memiliki kekuatan penjelas dalam menjelaskan average return pada semua wilayah (Amerika Utara, Eropa, Jepang, dan Asia Pasifik).

Penelitian-penelitian di atas secara umum menyimpulkan bahwa model lima faktor FamaFrench lebih baik dalam menjelaskan excess return portofolio saham dibandingkan dengan model tiga faktor Fama-French. Temuan terkait faktor bookto-market yang bersifat redundant menunjukkan hasil yang berbeda untuk pasar saham Amerika Serikat dan Australia.

\section{METODE}

\section{Data}

Data yang digunakan dalam penelitian ini adalah data sekunder yang diperoleh dari Thomson Reuters Datastream. Penggunaan sumber data Thomson Reuters Datastream membantu mengatasi survivorship bias dikarenakan sampel Datastream mengikutsertakan perusahaan aktif dan non aktif (Cakici, et al., 2013). Periode penelitian adalah Juli 2000 - Juni 2015. Data yang digunakan meliputi harga penutupan saham, jumlah saham yang beredar, indeks harga saham, nilai buku ekuitas, riskfree rate, laba operasi (operating income), beban bunga, dan total aset. Penelitian ini menggunakan mata uang Rupiah. Risk-free rate menggunakan data bulanan dari 90 hari Sertifikat Bank Indonesia (SBI).

Penelitian ini mengikuti Fama \& French (1992, 1993, 2015a) dalam kriteria pengambilan sampel. Adapun kriteria pengambilan sampel yang digunakan adalah: (1) tidak memasukkan sahamsaham yang masuk dalam sektor keuangan; (2) tidak memasukkan saham-saham dengan ekuitas negatif; (3) perusahaan terpilih harus memiliki data laba operasi, beban bunga, dan nilai buku ekuitas untuk tahun $t-1$; dan (4) perusahaan terpilih harus memiliki data total aset untuk tahun $t-2$ dan $t-1$.

\section{Variabel Penelitian}

Variabel independen dalam penelitian ini adalah faktor asset pricing, yang terdiri dari market factor, size factor, value factor, profitability factor, dan investment factor. Perhitungan faktor asset pricing menggunakan sortir portofolio $2 \times 3$.

a. Market Factor $\left(\mathrm{R}_{\mathrm{m}}-\mathrm{R}_{\mathrm{f}}\right)$

Market factormerupakan selisih setiap bulan antara return pasar dengan risk-free rate.

b. Size Factor (SMB)

SMB (Small Minus Big) merupakan selisih setiap bulan antara rata-rata return pada sembilan portofolio saham kecil (small stock) dengan rata-rata return pada sembilan portofolio saham besar (big stock).

$$
\begin{aligned}
S M B_{\left(\frac{B}{M}\right)}= & \frac{(\text { Small Value }+ \text { Small Neutral }+ \text { Small Growt } h)}{3}- \\
& \frac{(\text { Big Value }+ \text { Big Neutral }+ \text { Big Growt } h)}{3} \\
S M B_{(O P)}= & \frac{(\text { Small Robust }+ \text { Small Neutral }+ \text { Small Weak })}{3}- \\
& \frac{(\text { Big Robust }+ \text { Big Neutral }+ \text { Big Weak })}{3} \\
S M B_{(I N V)}= & \frac{(\text { Small Conservative }+ \text { Small Neutral }+ \text { Small Aggressive })}{3}- \\
& \frac{(\text { Big Conservative }+ \text { Big Neutral }+ \text { Big Aggressive })}{3} \\
S M B= & \frac{S M B_{(B / M)}+S M B_{(O P)}+S M B_{(I N V)}}{3}
\end{aligned}
$$

c. Value Factor (HML)

HML (High Minus Low) merupakan selisih setiap bulan antara rata-rata return pada dua portofolio yang mempunyai rasio book-to-market tinggi dengan rata-rata return pada dua portofolio yang mempunyai rasio book-to-market rendah.

$$
\begin{aligned}
H M L= & \frac{(\text { Small Value }+ \text { Big Value })}{2}- \\
& \frac{(\text { Small Growt } h+\text { Big Growt } h)}{2}
\end{aligned}
$$

\section{d. Profitability Factor (RMW)}

RMW (Robust Minus Weak) merupakan selisih setiap bulan antara rata-rata return pada dua 
portofolio yang mempunyai operating profitability tinggi dengan rata-rata return pada dua portofolio yang mempunyai operating profitability rendah.

$$
\begin{aligned}
R M W= & \frac{(\text { Small Robust }+ \text { Big Robust })}{2}- \\
& \underline{(\text { Small Weak }+ \text { Big Weak })}
\end{aligned}
$$

\section{e. Investment Factor (CMA)}

CMA (Conservative Minus Aggressive) merupakan selisih setiap bulan antara rata-rata return pada dua portofolio dengan conservative investment dan rata-rata return pada dua portofolio dengan aggressive investment.

$$
\begin{aligned}
C M A= & \frac{(\text { Small Conservative }+ \text { Big Conservative })}{2}- \\
& \frac{(\text { Small Aggressive }+ \text { Big Aggressive })}{2}
\end{aligned}
$$

Penelitian ini menghitung excess return dari portofolio 25 Size-B/M, 25 Size-OP, dan 25SizeInv sebagai variabel dependen. Portofolio 25 SizeB/M,yang dibentuk di akhir setiap Juni, merupakan pertemuan antara 5 portofolio yang dibentuk berdasarkan size (kapitalisasi pasar) dengan 5 portofolio yang dibentuk berdasarkan book-to-mar$k e t$ ratio. Size untuk Juni tahun $t$ merupakan perkalian antara harga saham pada Juni tahun $t$ dengan jumlah saham beredar pada Juni tahun $t$. B/M untuk Juni pada tahun $t$ adalah nilai buku ekuitas pada akhir tahun fiskal $t-1$ terhadap kapitalisasi pasarpada Desember tahun $t$-1. Portofolio akan direbalance tiap tahun pada setiap akhir Juni tahun $t$. Portofolio 25 Size-OP dan 25 Size-Inv dibentuk dengan cara yang sama seperti portofolio 25 Size-B/ $\mathrm{M}$, namun variabel kedua yang disortir adalah operating profitability atau investment.

\section{Model Empiris}

Model empiris dalam penelitian ini adalah model tiga faktor Fama \& French (1993) dan model lima faktor Fama \& French (2015a), sebagaimana ditunjukkan sebagai berikut:

$$
\begin{aligned}
R_{p t}-R_{f t}= & a_{p}+b_{p}\left(R_{m t}-R_{f t}\right)+s_{p} S M B_{t}+h_{p} H M L_{t}+e_{p t} \\
R_{p t}-R_{f t}= & a_{p}+b_{p}\left(R_{m t}-R_{f t}\right)+s_{p} S M B_{t}+h_{p} H M L_{t}+ \\
& r_{p} R M W_{t}+c_{p} C M A_{t}+e_{p t}
\end{aligned}
$$

dimana $R_{p t}-R_{f t}$ adalah excess return portofolio pada periode $t, R_{m t}-R_{f t}$ adalah market factor pada periode $t$, adalah sizefactor pada periode $t$, adalah valuefactor pada periode $t$, adalah profitabilityfactor pada periode $t$, adalah investment factor pada periode $t$, dan adalah error term.

Penelitian ini menggunakan metode estimasi Ordinary Least Square (OLS). Metode perhitungan standard error dalam penelitian ini menggunakan estimator yang diajukan oleh Newey-West (1987). Nilai standard error yang telah dikoreksi ini disebut sebagai HAC (heteroscedasticity and autocorrelation consistent) standard errors atau Newey-West standard errors. Metode perhitungan standard error ini membuat metode OLS menjadi lebih robust terhadap isu heteroskedastisitas dan autokorelasi.

Penelitian ini menggunakan dua kriteria dalam mengevaluasi dan membandingkan performa model tiga faktor dan lima faktor Fama-French. Mengikuti Merton (1973), suatu model asset pricing yang dispesifikasi dengan baik akan menghasilkan intersep yang tidak signifikan berbeda dari nol. Klaim seperti ini merupakan standar yang ketat dalam menilai model asset pricing. Penelitian ini menilai kekuatan penjelas dari persamaan (10) dan (11) dari signifikansi pada intersep untuk masing-masing model. Penelitian ini juga melihat rata-rata adjusted $R^{2}$ pada setiap model untuk menguji model asset pricing mana yang lebih baik dalam menjelaskan variasi return saham di Indonesia. Model asset pricing dengan nilai rata-rata adjusted $R^{2}$ yang lebih tinggi menandakan bahwa model tersebut lebih baik.

Untuk menguji apakah faktor book-to-market (HML) bersifat redundant atau tidak dalam menjelaskan excess returnportofolio saham di Indonesia, penelitian ini melakukan regresi dari suatu 


\section{Jurnal Keuangan dan Perbankan | KEUANGAN}

Vol. 20, No.3, September 2016: 343-357

faktor pada empat faktor lainnya dari model lima faktor Fama-French. Apabila nilai intersep dari HML mendekati nol dan tidak signifikan, maka dapat dikatakan bahwa faktor HML bersifat redundant dalam menjelaskan excess return portofolio saham di Indonesia.

Penelitian ini juga melakukan tes tambahan. Tes tambahan yang kami lakukan adalahuji beda intersep Indonesia dan US.

\section{HASIL}

\section{Statistik Deskriptif}

Deskripsi statistik untuk masing-masing variabel independen (faktor asset pricing) untuk periode Juli 2000 - Juni 2015 (180 observasi) dapat dilihat pada Panel ATabel 1. Nilai rata-rata dari marketexcess return $\left(\mathrm{R}_{\mathrm{m}}-\mathrm{R}_{\mathrm{f}}\right)$ adalah $0,62 \%$ per bulan, rata-rata bulanan dari faktor size (SMB) adalah $0,04 \%$, rata-rata bulanan dari faktor book-to-market (HML) adalah $0,03 \%$, rata-rata bulanan dari faktor profitability (RMW) adalah $0,02 \%$, dan rata-rata bulanan dari faktor investment (CMA) adalah -
0,0015\%. Semua faktor memiliki nilai rata-rata positif, kecuali faktor investment.

Panel B Tabel 1 menyajikan korelasi antar variabel independen. Faktor size dan profitability berkorelasi negatif dengan faktor market, sedangkan faktor book-to-market dan investment berkorelasi positif terhadap faktor market. Faktor book-to-market dan investment berkorelasi negatif dengan faktor size, sedangkan faktor profitability berkorelasi positif dengan faktor size. Faktor HML berkorelasi negatif dengan faktor profitability dan berkorelasi positif dengan faktor investment.

Tabel 2 meringkas rata-rata excess return bulanan dari portofolio 25 Size-B/M, 25 Size-OP, dan 25 Size-Inv untuk periode Juli 2000 sampai dengan Juni 2015 (180 observasi). Untuk portofolio 25 Size-B/M, saham-saham dalam kelompok kapitalisasi pasar kecil menunjukkan nilai excess return yang terus menurun, yaitu dari 0,016374 hingga -0,005978. Sementara saham-saham dalam kelompok kapitalisasi pasar besar menunjukkan fluktuasi. Hal ini mengisyaratkan bahwa rata-rata excessreturn kurang bisa ditangkap pada saham-

Tabel 1. Ringkasan Statistik Faktor Asset Pricing dan Korelasi

\begin{tabular}{|c|c|c|c|c|c|}
\hline \multicolumn{6}{|c|}{ Panel A: Ringkasan Statistik Faktor Asset Pricing } \\
\hline & $R_{m}-R_{f}$ & SMB & HML & RMW & CMA \\
\hline Mean & 0,006171 & 0,000435 & 0,000255 & 0,000224 & $-0,000015$ \\
\hline Median & 0,011935 & 0,000326 & 0,000142 & 0,000286 & 0,000145 \\
\hline Maximum & 0,193659 & 0,013950 & 0,039043 & 0,013332 & 0,017360 \\
\hline Minimum & $-0,321866$ & $-0,008444$ & $-0,014964$ & $-0,009326$ & $-0,018670$ \\
\hline Std dev. & 0,065175 & 0,002776 & 0,005769 & 0,002633 & 0,003024 \\
\hline \multicolumn{6}{|c|}{ Panel B: Korelasi } \\
\hline & $\mathrm{Rm}-\mathrm{Rf}$ & SMB & HML & RMW & CMA \\
\hline$R_{m}-R_{f}$ & 1 & $-0,3508$ & 0,257237 & $-0,135820$ & 0,158090 \\
\hline SMB & $-0,350836$ & 1 & $-0,594541$ & 0,177361 & $-0,356177$ \\
\hline HML & 0,257237 & $-0,594541$ & 1 & $-0,142409$ & 0,409642 \\
\hline RMW & $-0,135820$ & 0,177361 & $-0,142409$ & 1 & $-0,080010$ \\
\hline CMA & 0,158090 & $-0,356177$ & 0,409642 & $-0,080010$ & 1 \\
\hline
\end{tabular}


saham yang memiliki kapitalisasi pasar besar. Untuk portofolio 25 Size-OP, portofolio dengan operating profitability yang tinggi menunjukkan $e x$ cess return yang lebih tinggi daripada portofolio dengan operating profitability yang rendah dalam setiap kuintil size, kecuali dua kuintil size terakhir. Untuk portofolio 25 Size-Inv, rata-rata excessreturn saham yang memiliki kapitalisasi pasar yang rendah dan tinggi kurang bisa diamati atau ditangkap secara jelas.

\section{Uji Stasioneritas}

Tabel 3 menyajikan hasil uji stasioneritas dengan metode Augmented Dickey-Fuller(ADF) pada data level. Hasil pengujian stasioneritas pada tiap variabel penelitian menunjukkan bahwa seluruh variabel penelitian memiliki nilai $t$-stat yang lebih kecil daripada nilai kritis. Artinya, seluruh variabel penelitian telah bersifat stasioner (tidak mempunyai unit root) pada data level.

\section{Hasil Regresi untuk Portofolio 25 Size-B/M}

Untuk menyederhanakan penyajian, kami hanya menampilkan intersepdan rata-rata adjusted $R^{2}$ dari model tiga faktorFama-French pada setiap set portofolio 25. ${ }^{1}$ Untuk model lima faktor, kami menyajikan nilai intersep, koefisien dari lima faktor asset pricing, dan rata-rata adjusted $R^{2}$.

Tabel 4 meringkas hasil regresi untuk portofolio 25 Size-B/M. Panel A dan B menunjukkan

Tabel 2. Rata-rata Excess Return Bulanan pada Portofolio 25

\begin{tabular}{cccccc}
\hline \multicolumn{7}{c}{ Rata-rata Excess Return } \\
\hline \multicolumn{7}{c}{ Low } & 2 & 3 & 4 & High \\
\hline \multicolumn{7}{r}{ Panel A: Portofolio 25 Size-B/M } & & & & \\
Small & 0,016374 & 0,013786 & $-0,000212$ & $-0,004397$ & $-0,005978$ \\
2 & $-0,001620$ & 0,003320 & $-0,005950$ & $-0,005698$ & $-0,003746$ \\
3 & $-0,004737$ & $-0,005007$ & $-0,005008$ & $-0,003193$ & $-0,004173$ \\
4 & $-0,006621$ & $-0,006485$ & $-0,005722$ & $-0,004838$ & $-0,000689$ \\
Big & $-0,007129$ & $-0,008410$ & $-0,011906$ & $-0,001459$ & 0,001280 \\
Panel B: Portofolio 25 Size-OP & & & & \\
Small & $-0,002996$ & $-0,003484$ & $-0,005796$ & 0,008753 & 0,002207 \\
2 & $-0,006377$ & $-0,004849$ & $-0,003253$ & $-0,003160$ & 0,001170 \\
3 & $-0,004694$ & $-0,003580$ & $-0,001022$ & $-0,000042$ & 0,001281 \\
4 & $-0,000802$ & $-0,003992$ & $-0,003099$ & $-0,006003$ & $-0,005996$ \\
Big & 0,000003 & $-0,005897$ & $-0,005501$ & $-0,006555$ & $-0,007089$ \\
Panel C: Portofolio 25 Size-Inv & & & & \\
Small & $-0,004725$ & $-0,002952$ & $-0,002609$ & $-0,002953$ & $-0,000170$ \\
2 & $-0,005053$ & $-0,002948$ & $-0,001820$ & $-0,001620$ & $-0,001539$ \\
3 & $-0,001735$ & $-0,005007$ & $-0,004871$ & $-0,003748$ & $-0,005296$ \\
4 & $-0,003755$ & $-0,003897$ & $-0,004842$ & $-0,004452$ & $-0,004675$ \\
Big & $-0,001240$ & $-0,003683$ & $-0,006030$ & $-0,006652$ & $-0,006922$ \\
\hline
\end{tabular}

Koefisien dari faktor market, SMB, dan HML relatif sama untuk model tiga faktor dan lima faktor Fama-French. 


\section{Jurnal Keuangan dan Perbankan | KEUANGAN}

Vol. 20, No.3, September 2016: 343-357

hasil untuk model tiga faktor dan lima faktor FamaFrench. Panel A Tabel 4 menunjukkan bahwa terdapat 17 intersep yang signifikan pada tingkat $1 \%$. Hasil ini tidak sesuai dengan kriteria Merton (1973).
Pada Panel B Tabel 4, performa model lima faktor ditunjukkan guna sebagai perbandingan terhadap model tiga faktor. Seperti yang ditunjukkan pada Panel A Tabel 4, 17 intersep signifikan pada tingkat $1 \%$ untuk model tiga faktor. Hanya

Tabel 3. Hasil Uji Stasioneritas dengan Metode ADF

\begin{tabular}{|c|c|c|c|c|c|}
\hline$R_{m}-R_{f}$ & $-10,399670$ & & & & \\
\hline SMB & $-11,669890$ & & & & \\
\hline HML & $-10,308820$ & & & & \\
\hline RMW & $-12,200050$ & & & & \\
\hline CMA & $-10,802130$ & & & & \\
\hline \multicolumn{6}{|c|}{ Panel B: Excess Return Portofolio 25 Size-B/M } \\
\hline & Low & 2 & 3 & 4 & High \\
\hline Small & $-9,920994$ & $-13,834560$ & $-14,223280$ & $-6,563720$ & $-11,916670$ \\
\hline 2 & $-12,670350$ & $-5,462805$ & $-11,816230$ & $-8,633151$ & $-13,838370$ \\
\hline 3 & $-10,598610$ & $-10,035760$ & $-10,342880$ & $-8,267144$ & $-11,587340$ \\
\hline 4 & $-11,467590$ & $-19,348870$ & $-11,674620$ & $-12,141150$ & $-7,870897$ \\
\hline Big & $-11,146950$ & $-15,205420$ & $-9,032536$ & $-9,764417$ & $-7,631270$ \\
\hline \multicolumn{6}{|c|}{ Panel C: Excess Return Portofolio 25 Size-OP } \\
\hline & Low & 2 & 3 & 4 & High \\
\hline Small & $-16,876450$ & $-10,215140$ & $-11,133070$ & $-12,796950$ & $-12,763950$ \\
\hline 2 & $-9,970732$ & $-11,986230$ & $-10,677160$ & $-6,734021$ & $-13,104100$ \\
\hline 3 & $-9,812662$ & $-12,505940$ & $-6,606247$ & $-4,656736$ & $-8,872070$ \\
\hline 4 & $-11,464960$ & $-11,020440$ & $-12,402550$ & $-8,300373$ & $-9,752510$ \\
\hline Big & $-9,871076$ & $-9,407230$ & $-7,450181$ & $-12,059240$ & $-11,891590$ \\
\hline \multicolumn{6}{|c|}{ Panel D: Excess Return Portofolio 25 Size-Inv } \\
\hline & Low & 2 & 3 & 4 & High \\
\hline Small & $-11,652720$ & $-16,613310$ & $-11,434530$ & $-11,858940$ & $-11,492110$ \\
\hline 2 & $-11,751180$ & $-3,208107$ & $-13,747390$ & $-12,833670$ & $-11,359090$ \\
\hline 3 & $-9,746839$ & $-11,860530$ & $-11,623120$ & $-9,363605$ & $-11,292910$ \\
\hline 4 & $-11,412990$ & $-12,309450$ & $-5,349573$ & $-10,901230$ & $-11,312060$ \\
\hline Big & $-10,605070$ & $-10,867060$ & $-9,399867$ & $-11,983130$ & $-10,824480$ \\
\hline \multicolumn{6}{|c|}{ Nilai Kritis: } \\
\hline$a=1 \%$ & $-3,466994$ & & & & \\
\hline$a=5 \%$ & $-2,877544$ & & & & \\
\hline$a=10 \%$ & $-2,575381$ & & & & \\
\hline
\end{tabular}


terdapat satu koefisien dari faktor market yang tidak signifikan. Terdapat 13 koefisien dari faktor size (SMB) menunjukkan nilai positif yang signifikan. Koefisien SMB tidak memiliki pola jelas yang dapat diamati. Koefisien HML meningkat seiring sizepada portofolio dengan book-to-market ratio yang tinggi. Tidak ada pola yang jelas pada koefisien RMW dan CMA. Faktor RMW dan CMA berpengaruh lemah terhadap excess return portofolio saham di Indonesia. Hasil ini tidak serupa dengan temuan Fama \& French (2015a) dan Chiah, et al. (2015). Rata-rata adjusted $R^{2}$ pada portofolio 25 Size-B/M adalah 0,2419 untuk model tiga faktor dan 0,2613 untuk model lima faktor. Hasil ini mengindikasikan bahwa model lima faktor memiliki kekuatan penjelas yang lebih baik daripada model tiga faktor dalam menjelaskan variasi return saham.

\section{Hasil Regresi untuk Portofolio 25 Size-OP}

Tabel 5 menyajikan hasil regresi untuk portofolio 25 Size-OP. Panel A Tabel 5 menunjukkan hasil regresi untuk model tiga faktor. Terdapat 18 dari 25 portofolio memiliki intersep yang signifikan. Hasil ini cukup untuk menolak model tiga faktor sebagai deskripsi expected return pada portofolio 25 Size-OP. Rata-rata adjusted $R^{2}$ untuk model tiga faktor sebesar 0,237.

Panel B Tabel 5 melaporkan hasil regresi untuk model lima faktor Fama-French. Seperti yang ditunjukkan pada Panel A Tabel 4, terdapat 18 intersep yang signifikan pada model lima faktor. Semua koefisien dari faktor market signifikan. Sebagian besar koefisien SMB adalah positif dan signifikan. Terdapat 13 koefisien HML bernilai positif dan signifikan. Tidak ada pola yang jelas pada faktor SMB dan HML. Pada kuintil operating profitability terendah, koefisien RMW bernilai negatif yang semakin kuat seiring dengan meningkatnya size.Pola pada koefisien CMA tidak dapat diamati dengan jelas. Rata-rata adjusted $R^{2}$ untuk model lima faktor sebesar 0,2543 dimana nilai ini lebih besar dari rata-rata adjusted $R^{2}$ pada model tiga faktor. Hasil ini mendukung keunggulan model lima faktor Fama-French.

\section{Hasil Regresi untuk Portofolio 25 Size-Inv}

Hasil regresi untuk portofolio 25 Size-Inv disajikan pada Tabel 6. Panel A Tabel 6 menunjukkan hasil regresi untuk model tiga faktor. Semua intersep pada 25 portofolio bernilai negatif dan signifikan. Hasil ini tentu bertentangan dengan kriteria Merton (1973). Hal ini mengindikasikan bahwa model tiga faktor tidak cocok diterapkan di Indonesia. Nilai intersep semakin meningkat pada kuintil investment terendah.

Seperti hasil pada model tiga faktor, semua intersep bernilai negatif dan signifikan pada model lima faktor. Hasil ini mengonfirmasi bahwa model tiga faktor dan lima faktor Fama-French tidak valid di Indonesia. Semua koefisien dari faktor market bernilai positif dan signifikan pada tingkat $1 \%$. Pada kuintil investment tertinggi, koefisien HMl menunjukkan penurunan seiring dengan meningkatnya size. Tidak ada pola yang jelas pada koefisien RMW dan CMA. Rata-rata adjusted $R^{2}$ pada portofolio 25 Size-Inv adalah 0,2736 untuk model lima faktor dan 0,2515 untuk model tiga faktor. Hasil ini mengindikasikan bahwa model lima faktor lebih baik daripada model tiga faktor dalam menjelaskan excess return portofolio saham di Indonesia. 
Jurnal Keuangan dan Perbankan | KEUANGAN

Vol. 20, No.3, September 2016: 343-357

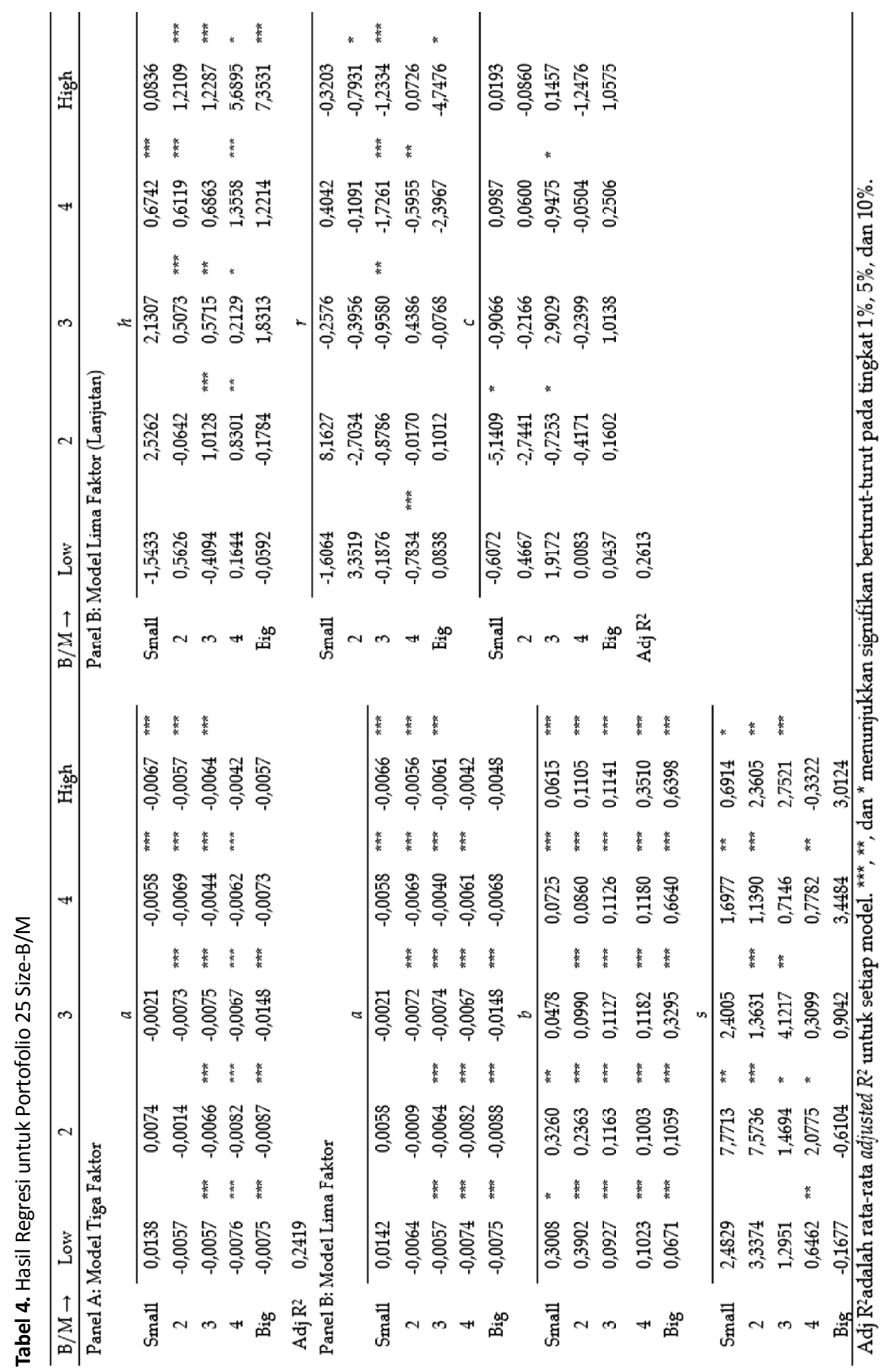


Uji Empiris Model Asset Pricing Lima Faktor Fama-French di Indonesia

Bambang Sutrisno \& Irwan Adi Ekaputra

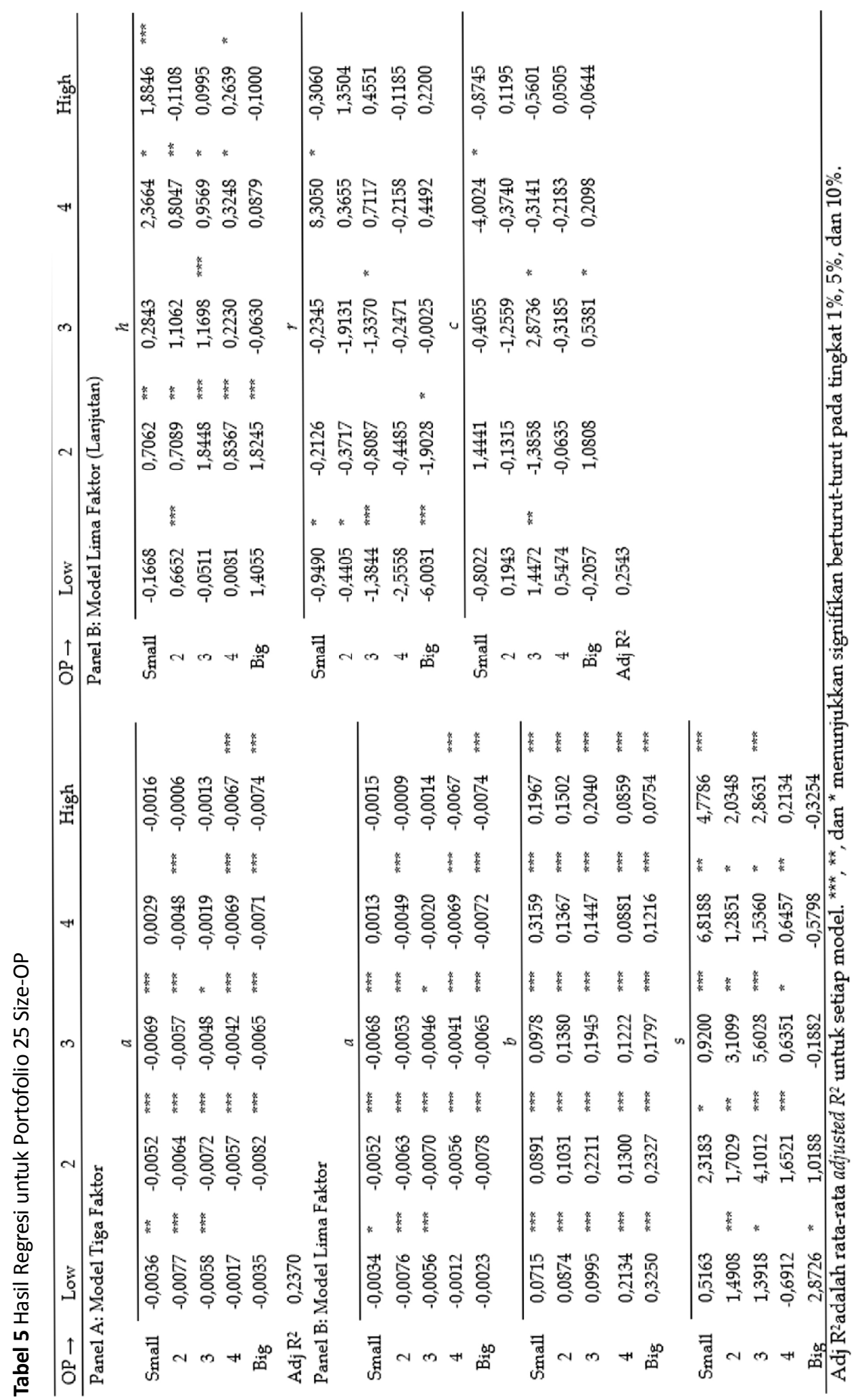




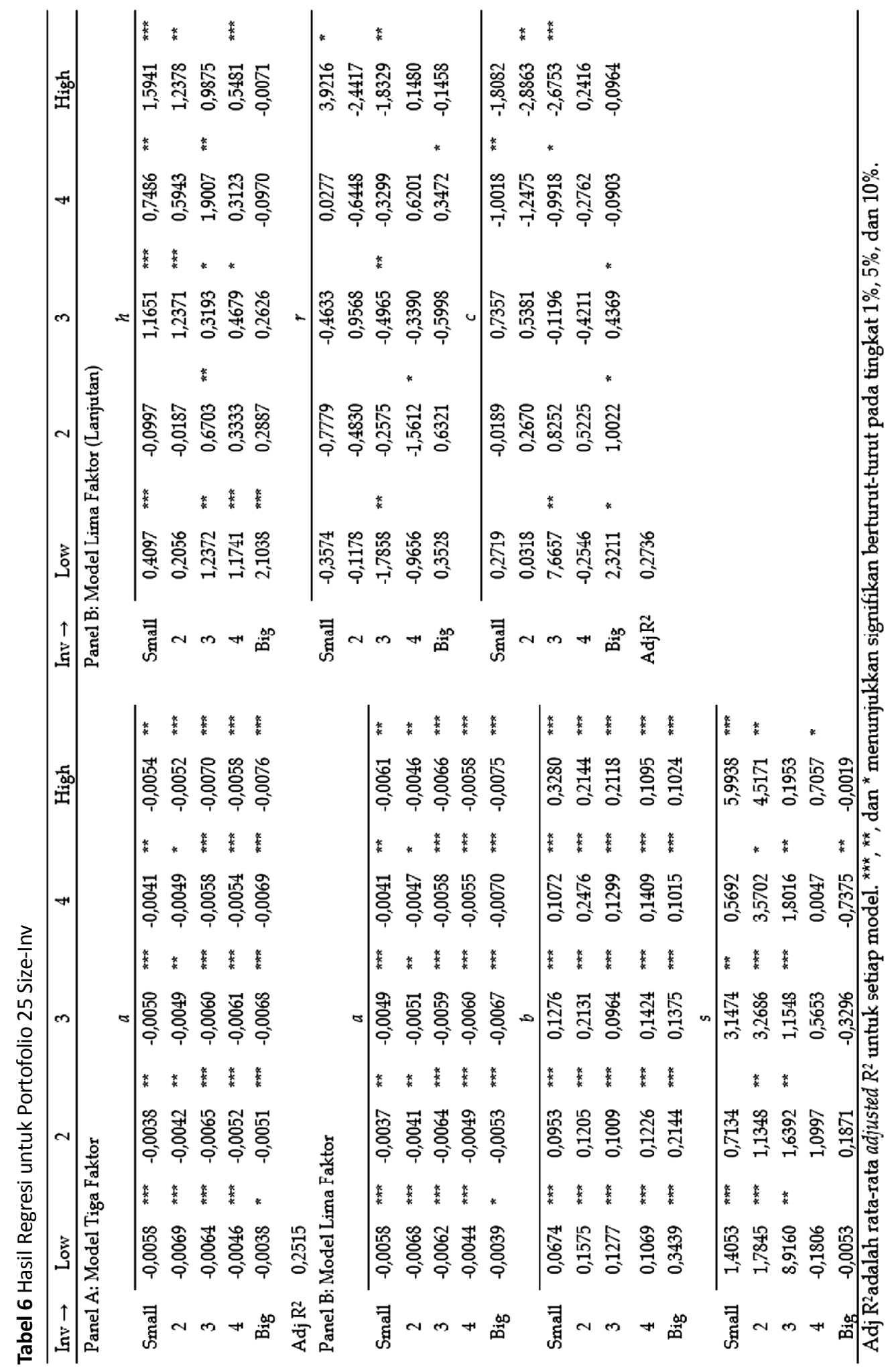


Apakah faktor book-to-market (HML) bersifat redundant?

Fama \& French (2015a) menemukan bahwa faktor book-to-market (HML) bersifat redundant dalam menjelaskan excess return saham di Amerika Serikat dengan adanya penambahan faktor profitability dan investment. Sebaliknya, Chiah, etal.(2015) menemukan bahwa faktor book-to-market tetap memiliki kekuatan penjelas dalam menjelaskan $e x$ cess return saham di Australia. Penelitian ini menguji apakah faktor book-to-marketbersifat redundant atau tidak di Indonesia. Hasil regresi faktor asset pricing ditunjukkan pada Tabel 7.

Hasil penelitian menunjukkan bahwa saat faktor HML diregres dengan empat faktor lainnya, nilai intersep mendekati nol dan tidak signifikan. Hasil ini mengindikasikan bahwa faktor HML bersifat redundant dalam menjelaskan excess return portofolio saham di Indonesia. Temuan ini konsisten dengan temuan Fama \& French (2015a).

\section{Uji Beda Intersep Indonesia dan US}

Tabel 8 dan 9 menyajikan hasil uji beda intersep Indonesia dan US pada model tiga faktor dan lima faktor Fama-French. Nilai p-valuepada setiap set portofolio 25 lebih kecil daripada tingkat signifikansi $5 \%$, baik pada model tiga faktor maupun model lima faktor. Artinya, ada beda intersep Indonesia dan US pada kedua model asset pricing Fama-French. Hal ini mengindikasikan bahwa ada perbedaan abnormal return di Indonesia dan US. Temuan ini juga menunjukkan bahwa ada perbedaan efisiensi pasar di kedua negara ini.

Tabel 7 Hasil Regresi Faktor Asset Pricing

\begin{tabular}{|c|c|c|c|c|c|c|c|c|c|c|c|c|}
\hline & Int & & $\mathbf{R}_{\mathrm{m}}-\mathbf{R}_{\mathbf{f}}$ & & SMB & & HML & & RMW & CMA & & $\mathbf{R}^{2}$ \\
\hline \multicolumn{13}{|l|}{$R_{m}-R_{f}$} \\
\hline Coef. & 0,0094 & & & & $-6,8501$ & & 0,7271 & & $-1,8103$ & 0,4731 & & 0,1323 \\
\hline t-Stat & 1,7757 & * & & & $-2,3603$ & $* *$ & 0,6192 & & $-0,6985$ & 0,2057 & & \\
\hline \multicolumn{13}{|l|}{ SMB } \\
\hline Coef. & 0,0005 & & $-0,0084$ & & & & $-0,2329$ & & 0,0758 & $-0,1111$ & & 0,4128 \\
\hline t-Stat & 2,8442 & $* * *$ & $-3,1119$ & $* * *$ & & & $-5,9581$ & $* * *$ & 0,6993 & $-0,5552$ & & \\
\hline \multicolumn{13}{|l|}{ HML } \\
\hline Coef. & 0,0007 & & 0,0039 & & $-1,0256$ & & & & $-0,0677$ & 0,4280 & & 0,4012 \\
\hline t-Stat & 1,5199 & & 0,6429 & & $-3,4825$ & $* * *$ & & & $-0,3789$ & 2,3818 & $* *$ & \\
\hline \multicolumn{13}{|l|}{ RMW } \\
\hline Coef. & 0,0002 & & $-0,0033$ & & 0,1117 & & $-0,0226$ & & & $-0,0043$ & & 0,0393 \\
\hline t-Stat & 1,0963 & & $-0,6913$ & & 0,6447 & & $-0,3938$ & & & $-0,0261$ & & \\
\hline \multicolumn{13}{|l|}{ CMA } \\
\hline Coef. & 0,0000 & & 0,0010 & & $-0,1822$ & & 0,1595 & & $-0,0048$ & & & 0,1878 \\
\hline t-Stat & 0,1104 & & 0,2052 & & $-0,5636$ & & 1,7282 & * & $-0,0261$ & & & \\
\hline
\end{tabular}

$* * *, * *$, dan $*$ menunjukkan signifikan berturut-turut pada tingkat $1 \%, 5 \%$, dan $10 \%$. 


\section{Jurnal Keuangan dan Perbankan | KEUANGAN}

Vol. 20, No.3, September 2016: 343-357

Tabel 8. Uji Beda Intersep Indonesia dan US (Model Tiga Faktor)

\begin{tabular}{cccc}
\hline Uraian & 25 Size-B/M & 25 Size-OP & 25 Size-Inv \\
\hline$p$-value & 0,0000 & 0,0000 & 0,0000 \\
\hline \multicolumn{4}{c}{$\mathrm{a}=5 \%$} \\
\hline
\end{tabular}

Tabel 9. Uji Beda Intersep Indonesia dan US (Model Lima Faktor)

\begin{tabular}{cccc}
\hline Uraian & 25 Size-B/M & 25 Size-OP & 25 Size-Inv \\
\hline$p$-value & 0,0000 & 0,0000 & 0,0000 \\
\hline \multicolumn{3}{c}{$\alpha=5 \%$} \\
\hline
\end{tabular}

\section{PEMBAHASAN}

Melalui uji empiris ini, model asset pricing Fama-French (baik tiga faktor maupun lima faktor) tidak valid di Indonesia. Indonesia sebagai negara emerging market memiliki pasar saham yang aktivitas perdagangannya masih rendah (thin trading) apabila dibandingkan dengan negara-negara lainnya, walaupun trading infrastructure-nya termasuk yang terbaik di dunia. Dimson (1979) dan Lo \& MacKinlay (1990) menyatakan bahwa suatu pasar yang mengalami thin trading kemungkinan besar akan mengalami nonsynchronous trading. Nonsynchronous trading sebagai implikasi dari thin trading menyebabkan level individual saham mempengaruhi level portofolio. Akibatnya, standard error akan overestimate atau underestimate sehingga banyak sekali koefisien yang signifikan atau banyak sekali yang tidak signifikan. Temuan empiris di Indonesia ini tidak mengejutkan karena efek thin trading dan nonsynchronous trading menyebabkan model asset pricing Fama-French tidak cocok diterapkan di Indonesia.

Hal lain yang perlu diperhatikan adalah secara fundamental, acuan risk-free rate di Indonesia sudah tidak sesuai dengan konsep risk-free rate dalam literatur asset pricing. Model Fama-French mengacu pada CAPM, APT, dan Merton, dimana risk-free rate menggunakan treasury bill yang meru- pakan fiscal authority, sedangkan Indonesia menggunakan SBI yang merupakan monetary authority. Fiscal authority kontributornya akan lebih besar daripada monetary authority. Monetary authority dimungkinkan juga ada isu pada likuiditasnya. Jadi, efek thin trading dan nonsynchronous trading(Dimson, 1979; Lo \& MacKinlay, 1990), serta risk-free rate tidak menggunakan fiscal authority menyebabkan bias yang terus-menerus pada hasil penelitian.

\section{KESIMPULAN}

Penelitian ini bertujuan untuk membandingkan model asset pricingtiga faktor dan lima faktor Fama-French dalam menjelaskan excess return portofolio saham di Indonesia dengan menggunakan kriteria zero intercept dari Merton (1973) dan rata-rata adjusted $R^{2}$ dari masing-masing model. Dengan adanya penambahan faktor profitability dan investment, penelitian ini juga menguji secara empiris apakah faktor book-to-market (HML) bersifat redundant dalam menjelaskan excess return portofolio saham di Indonesia. Penelitian ini menggunakan regresi time-series dengan frekuensi data bulanan.

Hasil penelitian menyimpulkan bahwa model lima faktor Fama-French memiliki kemampuan lebih baik dalam menjelaskan excess return portofolio saham di Indonesia dibandingkan dengan model tiga faktor Fama-French, walaupun faktor profitability dan investment berpengaruh lemah terhadap excess return. Intersep yang signifikan untuk uji empiris model asset pricing Fama-French di Indonesia pada setiap set portofolio 25 menunjukkan bahwa model Fama-French tidak valid di Indonesia. Dengan adanya penambahan faktor profitability dan investment, faktor book-to-market (HML) bersifat redundant dalam menjelaskan excess return portofolio saham di Indonesia. Temuan di Indonesia ini mendukung temuan Fama \&French (2015a) di US. Hasil uji beda intersep Indonesia dan US menunjukkan bahwa terdapat perbedaan abnormal return dan efisiensi pasar di Indonesia dan US. 


\section{SARAN}

Saran dalam penelitian ini ditujukan kepada dua pihak yaitu bagi akademisi dan praktisi. Bagi akademisi, perhitungan excess return dengan sortir portofolio $2 \times 4 \times 4$ disarankan untuk penelitian selanjutnya. Penggunaanrisk-free rate mengacu pada yield obligasi pemerintah dengan tenor kurang dari satu tahun dapat menjadi saran untuk penelitian selanjutnya. Melalui pengujian empiris model asset pricing Fama-French ini, investor disarankan untuk menggunakan model asset pricing yang lebih sederhana, mengingat faktor profitability dan investment memiliki hubungan yang lemahdalam menjelaskan excess return portofolio saham di Indonesia. Investor dapat memprediksi faktor-faktor apa saja yang dapat mempengaruhi excess return portofolio saham di Indonesia dengan model asset pricing yang lebih sederhana dan kemudian dapat mengambil strategi yang tepat dalam melakukan investasi.

\section{DAFTAR PUSTAKA}

Black, F., Jensen, M.C., Scholes, M. 1972. The Capital Asset Pricing Model: Some Empirical Tests. In Studies in the Theory of Capital Markets, edited by M.C. Jensen. New York: Praeger.

Cakici, N., Fabozzi, F.J. \&Tan, S. 2013. Size, Value, and Momentum in Emerging Market Stock Returns, Emerging Markets Review,16: 46-65.

Chiah, M., Chai, D. \&Zhong, A. 2015. A Better Model? An Empirical Investigation of the Fama-French FiveFactor Model in Australia. Unpublished Working Paper. Monash University.

Dimson, E. 1979. Risk Measurement when Shares are Subject to Infrequent Trading, Journal of Financial Economics, 7: 197-226.

Fama, E.F. \& French, K.R. 1992. The Cross-Section of Expected Stock Returns,Journal of Finance,47(2): 427465.

Fama, E.F. \& French, K.R. 1993. Common Risk Factors in the Returns on Stocks and Bonds,Journal of Financial Economics, 33: 3-56.

Fama, E.F. \& French, K.R. 1996. Multifactor Explanations of Asset Pricing Anomalies,Journal of Finance, 51: 55-84.
Fama, E.F. \& French, K.R. 1998. Value Versus Growth: The International Evidence,Journal of Finance, 53: 1975-1999.

Fama, E.F. \& French, K.R. 2012. Size, Value, and Momentum in International Stock Returns,Journal of Financial Economics, 105: 457-472.

Fama, E. F. \& French, K.R. 2015a. A Five-Factor Asset Pricing Model,Journal of Financial Economics, 116: 1-22.

Fama, E. F. \& French, K.R. 2015b. International Tests of a Five-Factor Asset Pricing Model. Unpublished Working Paper. University of Chicago.

Griffin, J.M. \& Lemmon, M.L. 2002. Book-to-Market Equity, Distress Risk, and Stock Returns,Journal of Finance, 57: 2317-2336.

IDX Statistics 2015.www.idx.co.id. (Diakses Tanggal 30 Maret 2016).

Lettau, M.\& Ludvigson, S. 2001. Resurrecting the (C)CAPM: A Cross-Sectional Test when Risk Premia are Time-Varying,Journal of Political Economy, 109: 1238-1287.

Lettau, M. \& Ludvigson, S. 2006. Do the Fama-French Factors Proxy for Innovations in Predictive Variables?,Journal of Finance, 61: 581-611.

Liew, J., Vassalou M. 2000. Can Book-to-Market, Size and Momentum be Risk Factors that Predict Economic Growth?,Journal of Financial Economics, 57(2): 221245.

Lintner, J. 1965. The Valuation of Risk Assets and the Selection of Risky Investments in Stock Portfolios and Capital Budgets, Review of Economics and Statistics, 47(1): 13-37.

Lo, A.W. \& MacKinlay, A.C. 1990. An Econometric Analysis of Nonsynchronous Trading,Journal of Econometrics, 45: 181-211.

Merton, R. 1973. An Intertemporal Capital Asset Pricing Model,Econometrica, 41(5): 867-887.

Newey, W.K. \& West K.D. 1987. A Simple Positive-Definite Heteroscedasticity and Autocorrelation-Consistent Covariance Matrix,Econometrica, 55: 703708.

Sharpe, W.F. 1964. Capital Asset Prices: A Theory of Market Equilibrium Under Conditions of Risk,Journal of Finance, 19(3): 425-442. 